\title{
A comparison of proximal femoral locking plate versus 95-degree angled blade plate in the treatment of reverse intertrochanteric fractures
}

\author{
Ters intertorakanterik kırıkların tedavisinde kilitli proksimal femur plağı ile \\ 95 derece açılı kamalı plağın karşılaştırılması
}

\author{
İbrahim Azboy, M.D., ${ }^{1}$ Abdullah Demirtaş, M.D., ${ }^{1}$ Mehmet Gem, M.D., ${ }^{1}$ \\ İdris Ahmet Çakır, M.D., ${ }^{2}$ Yılmaz Tutak, M.D. \\ 1Department of Orthopedics and Traumatology, Medical Faculty of Dicle University, Diyarbakır, Turkey \\ ${ }^{2}$ Department of Orthopedics and Traumatology, Yenimahalle State Hospital, Ankara, Turkey
}

\begin{abstract}
Objectives: This study aims to compare the results of the proximal femoral locking plate (PFLP) and the $95^{\circ}$-angled blade plate in the treatment of AO/OTA 31-A3 reverse intertrochanteric fractures with fracture line extending to the greater trochanter.

Patients and methods: Forty-four patients with reverse intertrochanteric fracture which fracture line extending to the greater trochanter were retrospectively analyzed. Of those, 20 were treated with PFLP (PFLP group) and 24 were treated with ABP (ABP group). The AO/OTA classification was used for the classification of the fractures. Patients were assessed clinically and radiologically for the union at the fracture site and implant-related complications. Hip functions were evaluated with the Harris hip score.
\end{abstract}

Results: The mean time to union was 17 weeks (range 14-28) and 18 weeks (range 16-32) in the PFLP group and ABP group, respectively. Implant failure and/or nonunion was observed in two patients $(10 \%)$ in the PFLP group and in three patients $(12 \%)$ in the ABP group. There was no statistically significant difference between the groups with regard to the Harris hip scores, time to union, need for reoperation due to mechanical problems, and complication rates ( $\mathrm{p}>0.05$ ).

Conclusion: Our study results show that these two fixation methods seem to produce similar results in the treatment of reverse intertrochanteric fractures with greater trochanteric comminution. However, we suggest that ABP still remains as a good choice with less expense in such fractures.

Key words: Complication; fracture healing; hip fracture; treatment failure.
Amaç: Bu çalışmada kırık çizgisinin trokanter majöre uzandı $\breve{g}_{1}$ AO/OTA 31-A3 tipi ters intertrokanterik kırıkların tedavisinde kilitli proksimal femur plağ kamalı plağın (ABP) sonuçları karşılaştırıldı.

Hastalar ve yöntemler: Kırık hattının trokanter majöre uzandığı ters intertrokanterik kırığı olan 44 hasta geriye dönük olarak incelendi. Bunlardan 20'si PFLP ile (PFLP grubu), 24'ü ise ABP ile (ABP grubu) tedavi edildi. Kırıkların sınıflamasında AO/OTA sınıflaması kullanıldı. Hastalar kırık bölgesinde kaynama ve implantlara bağlı komplikasyonlar açısından klinik ve radyolojik olarak değerlendirildi. Kalça fonksiyonları Harris kalça skoru ile değerlendirildi.

Bulgular: Ortalama kaynama süresi PFLP grubunda ve ABP grubunda sırasıyla 17 hafta (dağılım 14-18) ve 18 hafta (dağılım 16-32) idi. İmplant yetmezliği veya kaynamama PFLP grubunda iki hastada (\%10), ABP grubunda ise üç hastada (\%12) görüldü. Gruplar arasında Harris kalça skorları, kaynama zamanı, mekanik sorunlara bağlı yeniden ameliyat gereksimini ve komplikasyon oranları bakımından istatistiksel olarak anlamlı bir fark saptanmadı ( $>0.05)$.

Sonuç: Çalışma bulgularımız, büyük trokanterik parçalanmanın eşlik ettiği ters intertrokanterik kırıkların tedavisinde bu iki tespit yönteminin de benzer sonuçlar sağladığını göstermektedir. Bununla birlikte, bu tip kırıkların tedavisinde ABP'nin düşük maliyeti ile iyi bir seçenek olmayı sürdürdüğü kanısındayız.

Anahtar sözcükler: Komplikasyon; kırık iyileşmesi; kalça kırığı; tedavi başarısızlığı.

- Received: October 10, 2013 Accepted: February 12, 2014

- Correspondence: İbrahim Azboy, M.D. Dicle Üniversitesi Tıp Fakültesi Ortopedi ve Travmatoloji Anabilim Dalı, 21218 Diyarbakır, Turkey Tel: +90 505-6452433 Fax: +90412 - 2388111 e-mail: ibrahimazboy@hotmail.com 
The debate with regard to the treatment of reverse [AO/OTA (Arbeitsgemeinschaft für Osteosynthesefragen/Orthopedic Trauma Association) 31-A3] fractures of the proximal femur continues to exist. ${ }^{[1-8]}$ Recently, intramedullary nails have become widely accepted in the treatment of these fractures due to their biomechanical superiority. ${ }^{[7,9,10]}$ However, there are some challenges in the placement of nail and providing the reduction in these fractures, when the fracture line extends to the greater trochanter, particularly. Furthermore, complications including secondary trochanteric or femoral shaft fractures, peroneal nerve palsy, malrotation, instability, varus deformity, delayed union and nonunion can be observed in cases with the comminution of greater trochanter. ${ }^{[7,9,11]}$

Extramedullary implants are useful to minimize problems such as superior gluteal nerve injury, associated abductor weakness, and heterotopic ossification, which may likely to complicate intramedullary nailing. ${ }^{[2,12,13]}$ Although successful results were reported with the use of the traditional $95^{\circ}$-angled blade plate $(\mathrm{ABP}),^{[4,11,12]}$ the development of secondary varus collapse, cut out, and failure in these plates were observed. ${ }^{[4,11,12,14]}$

Recently, the proximal femoral locking plates (PFLPs) which have a fixed-angle stable construct and high pull-out strength have been developed to minimize possible complications in such fractures. ${ }^{[2,3,3,6,6,8,15,16]}$ Biomechanical studies indicate that PFLP provides either more axial stiffness, ${ }^{[17,18]}$ less torsional stiffness, ${ }^{[17]}$ or similar results ${ }^{[19]}$ compared to ABPs. On the other hand, PFLPs are three times more expensive compared to ABPs. Furthermore, despite the successful studies with the use PFLPs in pertrochanteric femoral fractures, ${ }^{[2,16,20]}$ high failure rates have been reported. ${ }^{[3]}$

To the best of our knowledge, there are no studies comparing PFLP and ABP in AO/OTA 31-A3 reverse intertrochanteric fractures with fracture line extending to the greater trochanter. The aim of this study was to compare the results of PFLP and ABP in the treatment of AO/OTA 31-A3 fractures of the proximal femur.

\section{PATIENTS AND METHODS}

\section{Study design}

A total of 52 patients who had been treated with the PFLP or ABP due to reverse fractures of proximal femur with fracture line extending to the greater trochanter (AO/OTA 31-A3) between 2007 and 2012 were retrospectively analyzed. Of these, two patients who died due to comorbidities and six patients who were lost to follow-up were excluded. A total of 44 patients were included in the study. Of those, 20 patients ( 17 males, 3 females, mean age 49 years, range 17 to 72 ) were treated with PFLP (PFLP group) and 24 patients (19 males, 5 females; mean age 45 years; range 18 to 68 ) were treated with $95^{\circ}$-APB (ABP group). In addition, patients with the followings were excluded from the study: pathologic fractures, rheumatoid arthritis treated with prolonged corticosteroid therapy, and missing follow-up.

In the PFLP group, one patient had Gustilo and Anderson $^{[21]}$ grade open 1 fracture, and two patients had grade 2 and in the ABP group.

In the PFLP group, the Locking Proximal Femur Plate (LPFP, Trpmed, İzmir, Turkey) were used. In the ABP group, 95o-angled blade plate (95 Açllı Plak, Hipokrat, İzmir, Turkey) were used.

\section{Surgical technique}

Surgery was performed with the patient supine on a radiolucent operating table. A straight lateral incision was made after the top of the greater trochanter palpated by the surgeon's index finger. To preserve the vascularity of comminuted fractures, small fracture fragments and medial side of the femur was protected. Reduction was performed before fixation. Then ABP or PFLP were inserted.

On the second day, patients were initiated to mobilize twice a day. Partial weight bearing was allowed at four weeks and was gradually increased as tolerated.

Patients were evaluated both clinically and radiographically at three, six, and 12 months postoperatively, and then till last follow-up. Using anteroposterior (AP) and lateral radiographs of the involved proximal femur region, fracture reduction and position of the implant were assessed. Quality of the reduction was classified as anatomical $(<5$ degrees of varus, valgus, anteversion or retroversion), acceptable (5-10 degrees) or poor ( $>10$ degrees). ${ }^{[7]}$ Fracture healing was assessed radiographically and was stated by documented healing of three of four cortices in the two radiographic planes. ${ }^{[22]}$ All patients were followed until complete union or a revision surgery was performed. Overall health before injury were determined by calculating the diverse comorbidities of the patients according to the American Society of Anesthesiologists (ASA) classification. ${ }^{[23]}$ Hip function was evaluated with the Harris hip score. ${ }^{[24]}$ 

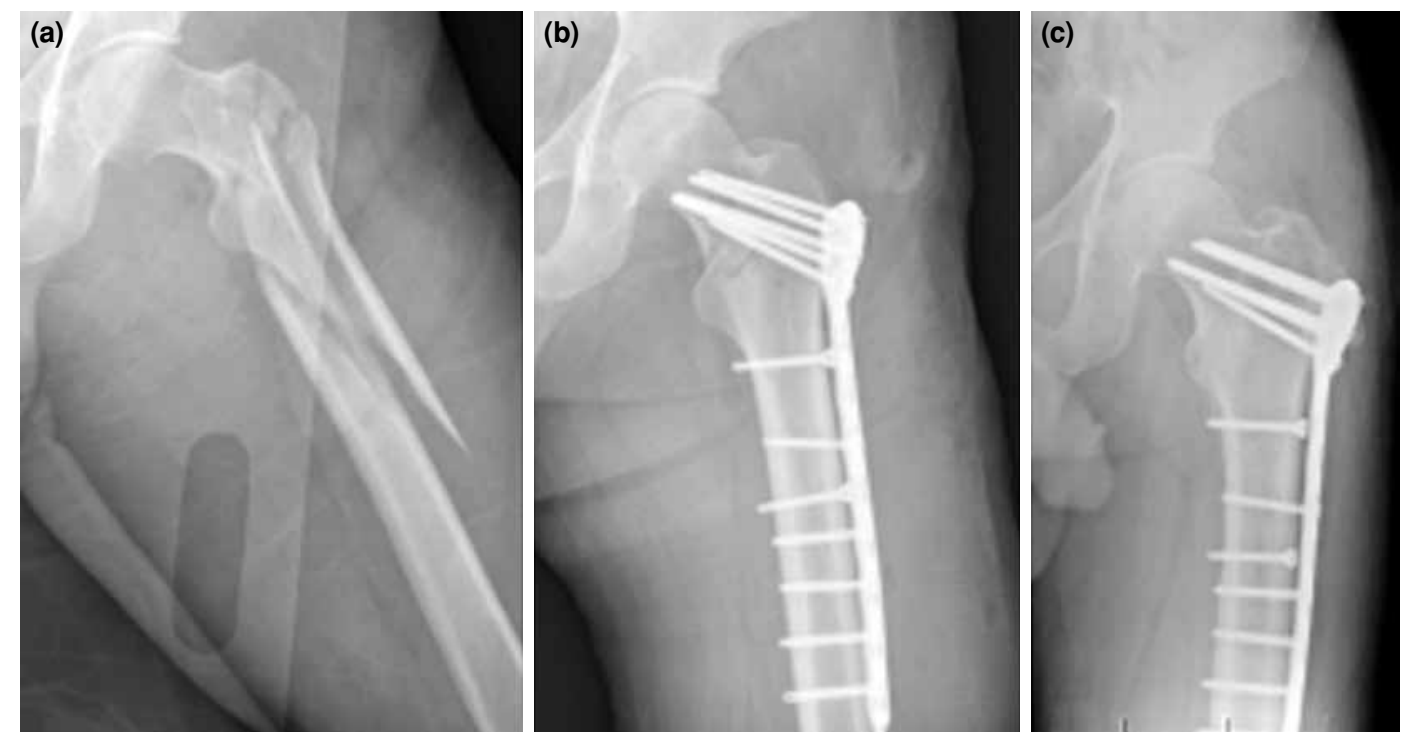

Figure 1. (a) Preoperative anteroposterior radiograph an AO/OTA 31-A3 reverse intertrochanteric fracture with fracture line extending to the greater trochater. (b) Anteroposterior-radiograph made two days after internal fixation with the proximal femoral locking compression plate. (c) Anteroposterior radiograph at 14 months.

\section{Statistical analysis}

Statistical analysis was performed using the SPSS version 17.0 software (SPSS Inc., Chicago, IL, USA). The Student t-test was used to identify differences between the independent groups. A Chi-square test was used to compare categorical variables. All statistical tests were two tailed, and a $p$ value of $<0.05$ was considered statistically significant.

\section{RESULTS}

The mean follow-up in the PFLP group was 24 months (range 18-30) and 28 months (range 19-26) in the ABP group. The mean time to union was 17 weeks (range 14-28) in the PFLP group (Figure 1) and 18 weeks (range 16-32) in the ABP group (Figure 2). The mean ASA score was 2.7 and 3.1 in the PFLP and $\mathrm{ABP}$ groups, respectively. There was no difference in time to union, and ASA scores between the
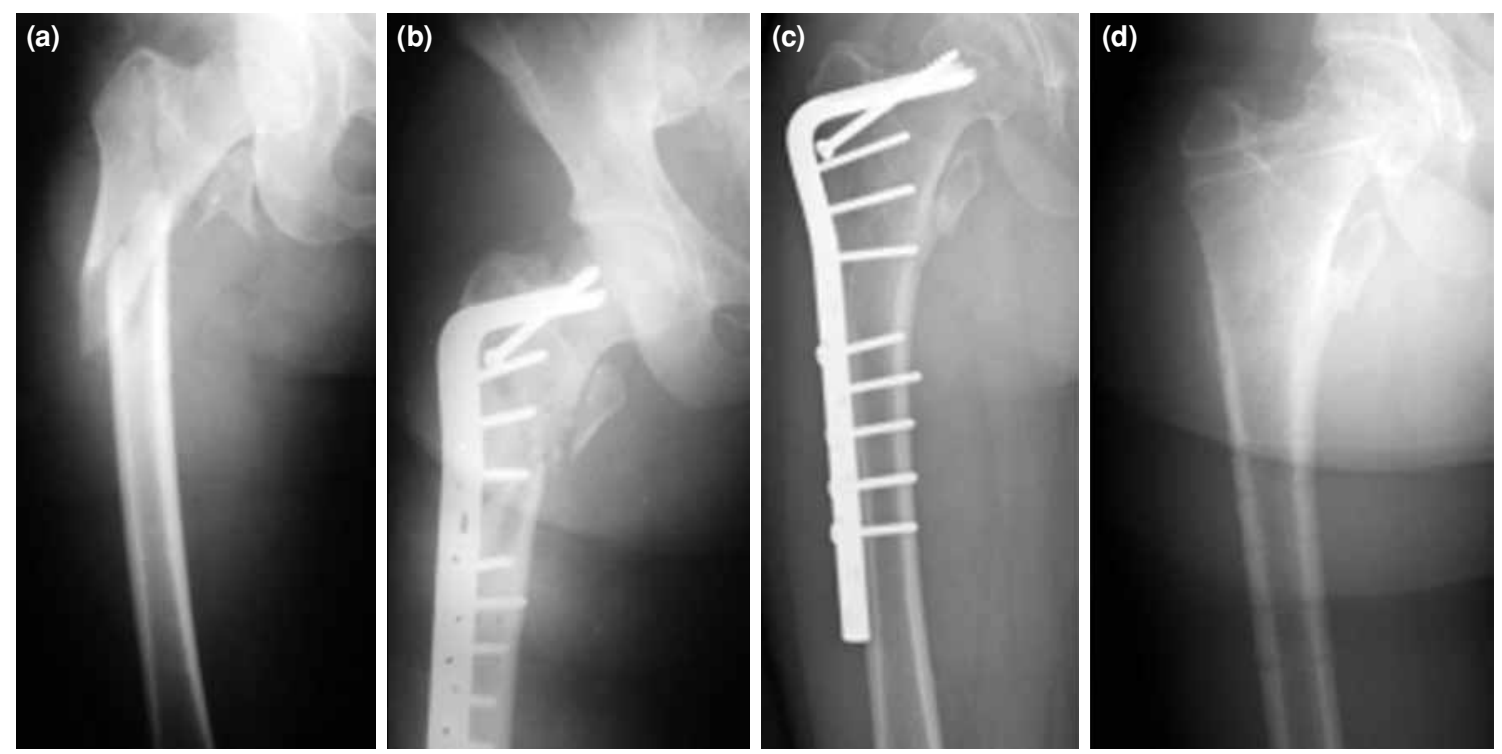

Figure 2. (a) Preoperative anteroposterior radiograph of an AO/OTA 31-A3 reverse intertochanteric fracture which fracture line extends to the greater trochanter; (b) Anteroposterior-radiograph made three days after internal fixation with the angled blade plate. (c) Anteroposterior-radiograph at 18 months of follow-up shows excellent fracture union. (d) Plate removed at 26 months after surgery. 
TABLE I

Radiographic outcomes at latest follow-up (chi-square)

\begin{tabular}{|c|c|c|c|c|c|}
\hline \multirow[t]{2}{*}{ Results } & \multicolumn{2}{|c|}{ PFLP group } & \multicolumn{2}{|c|}{ ABP group } & \multirow[b]{2}{*}{$p$} \\
\hline & $\mathrm{n}$ & $\%$ & $\mathrm{n}$ & $\%$ & \\
\hline Anatomical & 16 & 80 & 18 & 75 & \\
\hline Acceptable & 3 & 15 & 4 & 17 & 0.890 \\
\hline Poor & 1 & 5 & 2 & 8 & \\
\hline
\end{tabular}

PFLP: Proximal femoral locking compression plate; ABP: $95^{\circ}$ angled blade plate.

groups (for both; $\mathrm{p}>0.05$ ). Radiological results were similar in both groups $(\mathrm{p}>0.05)$ (Table I). The mean Harris hip score was 74.34 (range 62-94) in the PFLP group and 70.22 (range 56-92) in the ABP group. There was no significant difference in the Harris hip scores between the two groups ( $p>0.05$ ) (Table II).

Nonunion was observed in two patients $(10 \%)$ in the PFLP group and three patients (12\%) in the ABP group. Nonunion following the plate fracture was observed in two patients in the $\mathrm{ABP}$ group. Revision was performed followed by ABP and intramedullary nailing. Union was achieved in these patients. Plate cut-out was observed in one patient in the ABP group and treated with total hip arthroplasty. Nonunion was observed in two patients in the PFLP group after screwcut-out and plate fracture, and treated with total hip replacement followed by ABP. In each group, one patient had delayed union. Both patients had open fractures. However, in those two cases, the fractures healed without any need for an additional surgical procedure. There were two cases of malunion in the ABP group and one case in the PFLP group. Superficial infection was encountered in one case in the PFLP group and in two cases in the ABP group. They both recovered with local wound care and antibiotic treatment. There was no difference in the rate of implant failure and complications between the two groups (for each; $\mathrm{p}>0.05$ ).

\section{DISCUSSION}

In the present study, we compared the PFLP and $A B P$ results in the treatment of AO/OTA 31-A3 intertrochanteric fractures with fracture line extending to the greater trochanter. We obtained similar results in terms of, time to union, Harris hip score, implant failure and complication rates.

In a series of 35 patients with Seinsheimer type 3-5 comminuted subtrochanteric fractures, Saini et al. ${ }^{[2]}$ used PFLP. All patients achieved union, which occurred in an average of 15.6 weeks. There were two cases of delayed union, one case of malunion, and two cases of shorthening of $1 \mathrm{~cm}$. The authors concluded that the precontured nature of PFLP avoided malreduction and additional inferomedial Kickstand screw offered additional support to prevent collapse. Similarly, Zha et al. ${ }^{[25]}$ performed PFLP on 110 cases with intertrochanteric and subtrochanteric fractures (22 cases were A1, 70 cases were A2, and 18 cases were $\mathrm{A} 3$ ), and reported implant breakage in one case, nonunion in one case, and superficial infection development in two cases. The authors found that PFLPs might be a feasible alternative for the treatment of intertrochanteric and subtrochanteric fractures. Oh et al. ${ }^{[20]}$ used PFLP in 20 cases with subtrochanteric fractures and reported a mean union time of 20 weeks without any case of implant failure. The authors demonstrated that these findings might be attributed to the use of a total of six locked screws which fixed the femoral head and the choice of minimally invasive osteosynthesis.

On the other hand, Wirtz et al ${ }^{[3]}$ used PFLP in 19 patients (mean age: 59 years) with trochanteric fractures and reported secondary varus collapse in four patients, cut out in two patients, and proximal screw fracture in one patient. The authors suggested that the small size and number of proximal screws, which may have been insufficient to provide stable fixation of the proximal fragment might be the reason for the high failure rate $(37 \%)$.

TABLE II

Functional results of patients at latest follow-up using Harris hip score

\begin{tabular}{|c|c|c|c|c|c|c|}
\hline \multirow[t]{2}{*}{ Hip score (points) } & \multirow[t]{2}{*}{ Results } & \multicolumn{2}{|c|}{ PFLP group } & \multicolumn{2}{|c|}{ ABP group } & \multirow[b]{2}{*}{$p$} \\
\hline & & $n$ & $\%$ & $\mathrm{n}$ & $\%$ & \\
\hline $90-100$ & Excellent & 9 & 45 & 8 & 33 & \multirow{4}{*}{0.367} \\
\hline $80-89$ & Good & 7 & 35 & 10 & 42 & \\
\hline $70-89$ & Fair & 3 & 15 & 5 & 21 & \\
\hline$\leq 69$ & Poor & 1 & 5 & 1 & 4 & \\
\hline
\end{tabular}

PFLP: Proximal femoral locking compression plate; $\mathrm{ABP}: 95^{\circ}$ angled blade plate. 
Similarly, Streubel et al. ${ }^{[26]}$ used PFLP in patients who had OTA 31-A3 intertrochanteric fractures (mean age: 56 years) and reported a cumulative failure rate of $33 \%$ at 12 months. The high rate of failure in this study can be attributed to the use of two or three screws for fixation of the proximal part. Glassner and Tejwani ${ }^{[27]}$ reported failure in seven of 10 patients who underwent PFLP. Of these seven cases, two were with acute pertrochanteric fractures, one with a periprosthetic fracture at the site of a prior hip fusion, one with an early failure of a compression hip screw, and three with nonunion. The authors reported plate breakage in two cases, loss of fixation in three cases, and a combination of loss of fixation and screw breakage in two cases. In this study, the heterogeneity of primary diagnosis of the patients appears to be the main cause of treatment failures.

We used at least four screws with a thickness of $6.5 \mathrm{~mm}$ in the PFLP group which may explain the higher union rate $(90 \%)$ in our study. In addition, the decrease in bone quality with increasing age may increase the incidence of implant failures. We believe that the lower mean age of our patients (49 years in the PFLP group, and 45 years in the APB group) compared to the previous series ${ }^{[3,26]}$ might be an another reason for the high union rate of our study (90\% in PFLP, $88 \%$ in ABP, respectively). We should state that the fracture area should be opened during the conventional application of these ABPs. ${ }^{[5]}$ This, in turn, may impair the vascularity of bone, and thus, the union process. On the other hand, Çelebi et al. ${ }^{[14]}$ reported successful results using $\mathrm{ABP}$ with minimally invasive technique. In both group, we gave great caution to preserve the vascularity of bone using minimally invasive technique. This also may explain the high union rate of our series. In our study, the mean time to union was 17 weeks, and 18 weeks in the in the PFLP group and ABP group, respectively. The mean Harris hip scores were 74.34 and 70.22 in the PFLP and APB groups, respectively. Our results are consistent with the literature data. ${ }^{[2,20]}$

On the other hand, there are some limitations to this study. Firstly, it was in a retrospective design with a relatively small sample size. Secondly, we were not able to compare the subgroups of the AO/OTA 31-A3 intertrochanteric fractures e.g. osteoporotic fractures. ${ }^{[28]}$ However, further studies consisting of homogeneous subgroup types with similar degree of osteoporotic bone can reveal more accurate results on indications and effectiveness of PFLP and ABP.

In conclusion, in the present study, we imply that PFLP and ABP have similar functional and radiological results in the treatment of AO/OTA 31-A3 reverse intertrochanteric fractures with fracture line extending to the greater trochanter. Therefore, we believe that in certain situations which are challenging for intramedullary nailing, the ABP or PFLP can be used as a good alternative; although ABP may be preferred mostly to reduce cost.

\section{Declaration of conflicting interests}

The authors declared no conflicts of interest with respect to the authorship and/or publication of this article.

\section{Funding}

The authors received no financial support for the research and/or authorship of this article.

\section{REFERENCES}

1. Marsh JL, Slongo TF, Agel J, Broderick JS, Creevey W, DeCoster TA, et al. Fracture and dislocation classification compendium - 2007: Orthopaedic Trauma Association classification, database and outcomes committee. J Orthop Trauma 2007;21:S1-133.

2. Saini P, Kumar R, Shekhawat V, Joshi N, Bansal M, Kumar S. Biological fixation of comminuted subtrochanteric fractures with proximal femur locking compression plate. Injury 2013;44:226-31.

3. Wirtz C, Abbassi F, Evangelopoulos DS, Kohl S, Siebenrock KA, Krüger A. High failure rate of trochanteric fracture osteosynthesis with proximal femoral locking compression plate. Injury 2013;44:751-6.

4. Kinast C, Bolhofner BR, Mast JW, Ganz R. Subtrochanteric fractures of the femur. Results of treatment with the 95 degrees condylar blade-plate. Clin Orthop Relat Res 1989;122-30.

5. Yilmaz E, Karakurt L, Güzel H, Serin E. Evaluation of treatment results with the 95-degree AO/ASIF angular plate in subtrochanteric femur fractures. Eklem Hastalik Cerrahisi 2005;16:42-8.

6. Eksioglu F, Gudemez E, Cavusoglu T, Sepici B. Treatment of intertrochanteric fractures by external fixation. Bull Hosp Jt Dis 2000;59:131-5.

7. Ozkan K, Eceviz E, Unay K, Tasyikan L, Akman B, Eren A. Treatment of reverse oblique trochanteric femoral fractures with proximal femoral nail. Int Orthop 2011;35:595-8.

8. Subaşı M, Kesemenli C, Kapukaya A, Tüzüner T, Necmioğlu S, Kırkgöz T, Segmenter femur krıklarının cerrahisi. Eklem Hastalik Cerrahisi 2000;11:32-7.

9. Sadowski C, Lübbeke A, Saudan M, Riand N, Stern R, Hoffmeyer P. Treatment of reverse oblique and transverse intertrochanteric fractures with use of an intramedullary nail or a 95 degrees screw-plate: a prospective, randomized study. J Bone Joint Surg [Am] 2002;84:372-81.

10. Chou DT, Taylor AM, Boulton C, Moran CG. Reverse oblique intertrochanteric femoral fractures treated with the intramedullary hip screw (IMHS). Injury 2012;43:817-21.

11. Haidukewych GJ, Israel TA, Berry DJ. Reverse obliquity fractures of the intertrochanteric region of the femur. J Bone Joint Surg Am 2001;83-A:643-50.

12. Yoo MC, Cho YJ, Kim KI, Khairuddin M, Chun YS. Treatment of unstable peritrochanteric femoral fractures 
using a 95 degrees angled blade plate. J Orthop Trauma 2005;19:687-92.

13. Ozsoy MH, Basarir K, Bayramoglu A, Erdemli B, Tuccar E, Eksioglu MF. Risk of superior gluteal nerve and gluteus medius muscle injury during femoral nail insertion. J Bone Joint Surg [Am] 2007;89:829-34.

14. Celebi L, Can M, Muratli HH, Yagmurlu MF, Yuksel HY, Bicimoğlu A. Indirect reduction and biological internal fixation of comminuted subtrochanteric fractures of the femur. Injury 2006;37:740-50.

15. Wagner M. General principles for the clinical use of the LCP. Injury 2003;34 Suppl 2:B31-42.

16. Hasenboehler EA, Agudelo JF, Morgan SJ, Smith WR, Hak DJ, Stahel PF. Treatment of complex proximal femoral fractures with the proximal femur locking compression plate. Orthopedics 2007;30:618-23.

17. Crist BD, Khalafi A, Hazelwood SJ, Lee MA. A biomechanical comparison of locked plate fixation with percutaneous insertion capability versus the angled blade plate in a subtrochanteric fracture gap model. J Orthop Trauma 2009;23:622-7.

18. Floyd JC, O'Toole RV, Stall A, Forward DP, Nabili M, Shillingburg D, et al. Biomechanical comparison of proximal locking plates and blade plates for the treatment of comminuted subtrochanteric femoral fractures. J Orthop Trauma 2009;23:628-33.

19. Forward DP, Doro CJ, O'Toole RV, Kim H, Floyd JC, Sciadini MF, et al. A biomechanical comparison of a locking plate, a nail, and a $95^{\circ}$ angled blade plate for fixation of subtrochanteric femoral fractures. J Orthop Trauma 2012;26:334-40.

20. Oh CW, Kim JJ, Byun YS, Oh JK, Kim JW, Kim SY, et al. Minimally invasive plate osteosynthesis of subtrochanteric femur fractures with a locking plate: a prospective series of 20 fractures. Arch Orthop Trauma Surg 2009;129:1659-65.

21. Gustilo RB, Anderson JT. Prevention of infection in the treatment of one thousand and twenty-five open fractures of long bones: retrospective and prospective analyses. J Bone Joint Surg [Am] 1976;58:453-8.

22. McKibbin B. The biology of fracture healing in long bones. J Bone Joint Surg [Br] 1978;60:150-62.

23. Mak PH, Campbell RC, Irwin MG; American Society of Anesthesiologists. The ASA Physical Status Classification: inter-observer consistency. American Society of Anesthesiologists. Anaesth Intensive Care 2002;30:633-40.

24. Harris WH. Traumatic arthritis of the hip after dislocation and acetabular fractures: treatment by mold arthroplasty. An end-result study using a new method of result evaluation. J Bone Joint Surg [Am] 1969;51:737-55.

25. Zha GC, Chen ZL, Qi XB, Sun JY. Treatment of pertrochanteric fractures with a proximal femur locking compression plate. Injury 2011;42:1294-9.

26. Streubel PN, Moustoukas MJ, Obremskey WT. Mechanical failure after locking plate fixation of unstable intertrochanteric femur fractures. J Orthop Trauma 2013;27:22-8.

27. Glassner PJ, Tejwani NC. Failure of proximal femoral locking compression plate: a case series. J Orthop Trauma 2011;25:76-83.

28. Gül O, Atik OS, Erdoğan D, Göktaş G, Elmas C. Transmission and scanning electron microscopy confirm that bone microstructure is similar in osteopenic and osteoporotic patients. Eklem Hastalik Cerrahisi 2013;24:126-32. 